The Geneva Papers on Risk and Insurance, 23 (No. 86, January 1998) 34-51

\title{
The Corporate Demand for Insurance: A Strategic Perspective
}

\author{
by S. G. Ashby* and S. R. Diacon**
}

\begin{abstract}
The purpose of this paper is to discuss the possibility that decisions on corporate insurance purchases may have a strategic dimension. The conventional literature has focused on the ability of insurance to add value to the firm by limiting the impact of risk on risk averse stakeholders or reducing the cost of such risk. The key argument in this paper is that, under certain circumstances, the corporate demand for insurance may be motivated by a company's strategic decisions on output and price risk. Most real world markets are characterised by small numbers of relatively large firms which compete with each other strategically. By focusing on such oligopolistic markets, we reveal that this interdependency between firms means that insurance and risk management can also have a strategic consequence. The strategic behaviour of the firm may influence risk management in general, and the corporate purchase of insurance in particular, in three main ways: first, the strategic nature of competition may provide an incentive for even risk neutral firms to control risk; secondly the firm's risk control decisions cannot be made in isolation but will depend on the actions of its rivals, and thirdly insurance (as opposed to other risk control mechanisms) may play a role in facilitating cooperation or coordination between competing firms for their mutual benefit.
\end{abstract}

\section{Introduction}

Very little information is available on the extent of commercial insurance purchases. What little insight there is seems to suggest that industrial and commercial business continues to spend large amounts on insurance protection. In a survey of the largest 500 industrial corporations in the US, Main (1982) found that $55 \%$ of respondents claimed to insure over three-quarters of their perceived insurable risks. Similarly in a questionnaire survey of the risk managers of the largest 127 quoted UK industrial companies, Ashby \& Diacon (1996a) noted that $43 \%$ of respondents thought that full - or virtually full - insurance was the most suitable level of cover for their company's assets. More precise figures on the insurance purchases of US corporations can be obtained from the "Cost of Risk" survey: in 1993,

\footnotetext{
${ }^{*}$ Sheffield Hallam University.

** University of Nottingham.
} 
US-based companies reported total risk costs averaging $0.77 \%$ of corporate revenues, almost one-half of which was property, liability and workers' compensation insurance premiums (Towers Perrin, 1994).

The existing literature on the corporate demand for insurance has focused on the ability of insurance to add value to the firm by limiting the impact of risk on risk averse stakeholders or reducing the cost of such risk. The key argument in this paper is that, under certain circumstances, insurance may be purchased for strategic reasons. Most real world markets are charactrised by small numbers of relatively large firms which compete with each other strategically. By focusing on such oligopolistic markets we reveal that a single firm may gain a significant competitive advantage by manipulating its exposure to output risk, since such behaviour can expose rivals to price fluctuations.

The discussion proceeds in a number of sections. We begin by providing a short review of the conventional literature on the corporate demand for insurance and summarise the main arguments under five main headings. One characteristic of the existing literature is the paucity of evidence ${ }^{1}$ - consequently the next section reports some results from a small survey of UK stock analysts to explore the "stock market" attitude towards corporate insurance. The remaining sections of the paper attempt to develop some ideas on why the purchase of property and liability insurance by commercial companies might be motivated by strategic reasons. A more technical illustration of the arguments is provided in a brief appendix.

\section{The corporate demand for insurance}

A summary of the traditional factors determining the corporate purchase of insurance is provided in Table 1: a common feature is the use of insurance to either reduce risk or to reduce the various costs of risk.

The starting point is the insistence by many authors (such a Mayers \& Smith, 1982; Grillet, 1992; and Doherty \& Smith, 1992) that shareholder risk aversion should not be the main motivation. This is because the shareholder of "widely-held" quoted companies will have already diversified away any unsystematic risk, and therefore behave towards insurance as if they were risk neutral.

Of course there may be other stakeholders in the firm, such as its managers, who are risk averse. In this case, insurance which stabilises corporate profits (and therefore the managers' profit-related remuneration) may be purchased by managers as part of a standard "second-best" solution to the principal-agent problem (Hay \& Morris, 1991; Parry \& Parry, 1991; Lypny, 1993). The case for managerial risk aversion as a driver of corporate risk management has received some recent empirical support in the work of Tufano (1996).

It is difficult to believe that all non-compulsory insurance is motivated by managerial risk aversion, and is always contrary to the interests to shareholders. The discussion has therefore moved on to include other motivating factors for the purchase of insurance which also serve to benefit risk neutral as well as risk averse stakeholders. Companies may decide

1 With the exception of Main (1982) who undertakes a questionnaire survey, Doherty \& Smith (1993) who report a case study of one company, and Mayers \& Smith (1990) who analyze insurance companies' demand for reinsurance. 
Table 1:

The corporate demand for insurance

\begin{tabular}{|c|c|}
\hline MOTIVATION & DESCRIPTION \\
\hline \multirow[t]{2}{*}{$\begin{array}{l}\text { Stakeholder risk } \\
\text { aversion }\end{array}$} & $\begin{array}{l}\text { The willingness of stakeholders (owners, bondholders, } \\
\text { employees, customers) to pay a sum, in excess of } \\
\text { expected losses, in order to exchange risk for certainty. } \\
\text { But shareholders and bondholders may be able to } \\
\text { remove unsystematic risk at less cost by holding a } \\
\text { widely diversified portfolio. }\end{array}$ \\
\hline & $\begin{array}{l}\text { The impact of risk on stakeholders who are not residual } \\
\text { claimants is determined by the terms of the contract } \\
\text { which binds them to the firm. }\end{array}$ \\
\hline $\begin{array}{l}\text { Cost-effective } \\
\text { administration }\end{array}$ & $\begin{array}{l}\text { Insurers may obtain economies of scale in administe- } \\
\text { ring the insurance pool. }\end{array}$ \\
\hline \multirow[t]{2}{*}{$\begin{array}{l}\text { "Give-away" } \\
\text { insurance prices }\end{array}$} & $\begin{array}{l}\text { Insurance premiums may be set below the present } \\
\text { value of expected losses because: }\end{array}$ \\
\hline & $\begin{array}{l}\text { - of the underwriting cycle } \\
\text { - insurers can obtain a higher yield on liquid assets } \\
\text { - information asymmetry }\end{array}$ \\
\hline \multirow{2}{*}{$\begin{array}{l}\text { Increasing the value } \\
\text { of the firm }\end{array}$} & Insurance may increase the value of the firm via: \\
\hline & $\begin{array}{l}\text { - a reduction in the expected costs of financial distress } \\
\text { or bankruptcy } \\
\text { - a reduction in liability to tax } \\
\text { - otherwise concave profit function }\end{array}$ \\
\hline \multirow[t]{2}{*}{$\begin{array}{l}\text { Controlling } \\
\text { "agency" costs }\end{array}$} & $\begin{array}{l}\text { The monitoring undertaken by insurers may be used to } \\
\text { ensure that one group of stakeholders does not } \\
\text { undertake actions to the detriment of others, in areas } \\
\text { such as: }\end{array}$ \\
\hline & $\begin{array}{l}\text { - "short-termism" among managers } \\
\text { - actions to increase risk-taking behaviour to the } \\
\text { detriment of bondholders or creditors } \\
\text { - the "underinvestment" problem } \\
\text { - monitoring health and safety standards } \\
\text { (eg engineering inspection) } \\
\text { - limiting externalities (eg compulsory insurance) }\end{array}$ \\
\hline
\end{tabular}


to purchase insurance because of the insurer's comparative advantage and cost effective administration in the organisation and administration of the insurance pool (providing what Mayers \& Smith (1982) term "real service efficiencies"), as insurers may have a comparative advantage over other forms of risk handling (Arrow, 1963). Furthermore competition in insurance markets may encourage efficiency in administrative activities performed by insurers, especially if economies of scale and scope can be obtained (Doherty \& Smith, 1993).

The corporate demand for insurance will also be stimulated if buyers perceive that the risk premium charged by insurers is below the expected present value of losses. This may arise in the short-term because of the occurrence of underwriting cycles, or because of cash flow underwriting, or arising from the insurer's inability to distinguish the buyer's high-risk status (for example, see Harrington \& Danzon, 1994).

It has also been argued that the corporate purchase of insurance may serve to increase the value of the firm in terms of the expected present value of the company's future cash flows. This may be achieved via a reduction in the transactions costs of financial distress or bankruptcy (Shapiro \& Titman, 1985; Rawls \& Smithson, 1990), a reduction in the liability to corporate taxation (Mayers \& Smith, 1982; Main 1983; Garven \& Loubergé, 1996), or simply because the firm's profits are a concave function of output ${ }^{2}$ (Gravelle \& Rees, 1992).

Finally the purchase of insurance may serve to reduce the incentive for some stakeholders to impose so-called agency costs on others: in this case, insurance is seen as the cure of the principal-agent problem, rather than the symptom (Holderness, 1990). This is possible because insurers are able to monitor managerial risk-taking (via the insurer's inspectors and surveyors ) and bond the firm's actions via contract terms and warranties (Skogh, 1989, 1991). Thus insurance may limit short-term behaviour of managers, and may prevent increases in risk to the detriment of banks or bondholders making fixed interest loans, or to the detriment of liability claimants (Mayers \& Smith, 1982). Insurance may also solve the socalled underinvestment problem (Myers, 1977; Mayers \& Smith, 1987) and is one possible solution to the imposition of externalities on employees, third parties or the environment (Freeman \& Kunreuther, 1996).

\section{The stock market view on corporate insurance}

In the light of the increasing interest in corporate disclosure, ${ }^{3}$ a survey was undertaken in Autumn 1993 to determine the reactions of stock analysts towards the purchase of insurance by quoted UK companies. To this end a questionnaire was circulated to 309 equity managers working in the UK (ie stock analysts and fund managers) monitoring listed UK manufacturing and distribution companies. A total of 59 replies were received, representing a response rate of 19 per cent.

In general, equity managers were very positively disposed towards the corporate purchase of insurance. For example, when asked to indicate "the most suitable level of property \& liability insurance cover for a typical UK manufacturing PLC company, from

2 Which would arise, for example, in the case of technological risk if there was a negative relationship between output and price. This discussed in more detail in the following sections.

${ }^{3}$ Stimulated by the report of the Cadbury Committee on corporate governance (Cadbury, 1992) which introduced a code of best practice that promoted improvements in the reporting of company performance and in internal controls. 
$1=$ Uninsured to $5=$ Fully Insured" 48 out of 59 ticked either 4 or 5 (ie over $80 \%$ ). ${ }^{4}$ These replies mirrored those from a similar question about the equity managers' own personal insurance coverage. Further questions were then asked about the purchase of insurance and the anticipated impact of the permanent cancellation of a company's insurance coverages the responses are summarised in Table 2 and 3.

Table 2 reports the attitudes of stock analysts towards the cancellation of corporate insurance. ${ }^{5}$ About $42 \%$ of stock analysts and equity managers expected the company's netof-tax profits to increase following the cancellation of its insurance contracts although a further quarter thought profits would either fall or remain unchanged. To a certain extent, these replies reflect the ambiguity of many academics on the value of corporate insurance (for example, see Williams, Smith \& Young, 1995, ch. 11). What is more surprising is the impact of insurance cancellation on shareholder risk: the vast majority of respondents determined that the risk to both individual and institutional investors would be increased by such a policy. This contrasts markedly with the "traditional" finance view that fully diversified widely-held shareholders (such as institutional shareholders) have already diversified away all unsystematic risk, so that the cancellation of insurance contracts cannot increase their risk (whereas this is not the case for individual shareholders).

Table 3 provides an indication of the views of stock analysts on why listed UK manufacturing or distribution companies might purchase non-compulsory property and liability insurance. Respondents were provided with a list of reasons and asked to rank each on a scale from " 1 = not important for most companies" to " 5 = very important for most companies". The average score in the final column indicates that, according to stock analyst respondents, the three most important reasons for the purchase of insurance are "to reduce the risk of bankruptcy or financial distress", "to ease the worries of bankers and other creditors" and "to ease the worries of Directors and Officers". These results are consistent with the implication drawn from Table 2 that the purchase of insurance is associated in the minds of the respondents with a lower risk of financial distress or corporate bankruptcy and associated costs. ${ }^{6}$

\section{Strategic behaviour and the response to risk}

Individuals are used to making strategic decisions: who to marry, what to buy, where to work etc. The strategic nature of decisions arises because they are not made in a vacuum; instead decision makers are surrounded by others whose choices interact and subsequently affect their own. In this respect firms are no different to individuals. Modern industry is characterised by oligopolistic markets which are dominated by small numbers of relatively large

${ }_{4}$ This contrasts with the $43 \%$ response from corporate risk managers who were asked the same question in Ashby \& Diacon (1996a).

${ }^{5}$ In part, this question was prompted by the well-publicised 1990 decision of British Petroleum to review its insurance strategy. The new strategy reversed the conventional insurance wisdom in order to insure only high frequency/low severity property and liability losses, and produced a saving of around $\$ 100$ million per annum (Doherty \& Smith, 1993).

${ }^{6}$ It is unclear however whether the purchase of insurance is the cause or the consequence of lower bankruptcy risk. Several authors argue that insurance reduces the risks of bankruptcy costs and /or bankruptcy (eg Mayers \& Smith, 1982) but Diacon 1991 points out that firms in more competitive industries (where the risk of bankruptcy is greater) are less likely to purchase insurance. 
Table 2: Stock market attitudes towards the cancellation of insurance cover* Sample size $=59$, August 1993

If following a careful review, a company cancelled permanently all its "external" insurance policies (except those which are compulsory under statute or contract), what would you expect to happen to :

\begin{tabular}{|c|c|c|c|c|}
\hline Question** & Decrease & Increase & Same & $?$ \\
\hline 1. Long run average net-of-tax profits & 7 & 24 & 7 & 19 \\
\hline 2. Risk to small individual shareholders & 0 & 45 & 6 & 6 \\
\hline 3. Risk to institutional shareholders & 1 & 42 & 7 & 6 \\
\hline
\end{tabular}

* Some questions had one or two non-replies.

** The following rubric was used to introduce these questions in the questionnaire: "These questions relate to the insurance coverage of typical UK manufacturing or distribution PLC companies whose ordinary shares are listed on the London Stock Exchange. The questions refer to insurance purchased from an "external" insurance company, rather than from an "internal" captive insurance subsidiary".

\section{Table 3: Stock market attitudes to the purchase of insurance*}

Sample size $=59$, August 1993

Why do many listed UK companies purchase some form of non-compulsory "external" property \& liability insurance for their business? Please score each of the following reasons on a scale from $1=$ not important for most companies to $5=$ very important for most companies. ${ }^{* *}$

- to increase gross trading profits

Average score

- to increase the value of the firm

- to reduce the risk of bankruptcy or financial distress

- to improve the interpretation of company profitability

- as a signal of management competence

- to ease the worries of Directors and Officers

- to ease the worries of non-executive staff

- to ease the worries of bankers and other creditors

- to ease the worries of small individual shareholders

- to ease the worries of institutional shareholders

- to ease the worries of employees

- to reduce the cost of capital

- to reduce liability to tax

- to reduce employment costs

- to constrain harmful managerial risk-taking behaviour

- to reduce systematic risk

- to reduce unsystematic risk

- to improve efficiency

- to provide funds for reinvestment

- to comply with contractual obligations

* Some questions had one or two non-replies.

** The following rubric was used to introduce these questions in the questionnaire: "These questions relate to the insurance coverage of typical UK manufacturing or distribution PLC companies whose ordinary shares are listed on the London Stock Exchange. The questions refer to insurance purchased from an "external" insurance company, rather than from an "internal" captive insurance subsidiary". 
firms (for example the oil/petrol, motor, chemical and computer industries). An important characteristic of such industries is that the firms within them are interdependent, that is to say the decisions of one firm will affect both the situation and the subsequent decisions of its competitors and vice-versa. This interdependence adds a strategic dimension to the behaviour and risk management of such firms, a dimension that has not been considered in any great detail in insurance and risk management research. ${ }^{7}$

One common area of interdependency is the relationship between one firm's output and consumers' demand for its rivals' products. A firm which increases its output of a particular product will generally need to accept a lower price, while one which does the opposite should find that the price of its product will rise. ${ }^{8}$ This, in turn, is likely to affect the demand for rival products as consumers either switch to the lowest price producer ${ }^{9}$ or substitute the entire product group with another (e.g. oil for gas or solar energy).

Because of the impact that one firm's production decisions may have on the demand for its rivals' products, it is vital that firms acquire as much information as they can about both the current and future output plans of their rivals. Of course, given the strategic importance of output related information firms are likely to keep the exact details of their production plans secret. Failure to properly predict its rivals' output may mean that the firm ends up misjudging the potential demand for its products. This, in turn, can have a serious effect on the firm's profitability and could even lead to bankruptcy. Over time, seasoned competitors should start to learn about and be able to predict the output decisions of their rivals, but this may be difficult in a turbulent environment. A rational, profit maximising, firm does not change its output without good cause, instead output is predominantly determined by its costs, which in the absence of random shocks largely remain fixed or move in a reasonably predictable manner. ${ }^{10}$

This interdependency between firms operating in oligopolistic industries means that insurance and risk management can also have a strategic consequence. We will see that the strategic behaviour of the firm may influence risk management in general, and the corporate purchase of insurance in particular, in three main ways: first the strategic nature of competition may provide an incentive for even risk neutral firms to control risk - and this is discussed in the remainder of this section. Secondly the firm's risk control decisions cannot be made in isolation but will depend on the actions of its rivals, and thirdly insurance (as opposed to other risk control mechanisms) may play a role in facilitating cooperation or coordination between competing firms for their mutual benefit. These latter points are dealt with in the two following sections.

7 This analysis is only designed to provide a basic introduction into the vast topic of strategic interaction, for a more in-depth study see Fudenberg \& Tirole (1986) of Shapiro (1989).

${ }^{8}$ The price that a firm can charge for a product will largely depend upon its availability. Where the supply of a good is plentiful a firm will need to reduce its price in order to ensure that all of it is sold. Conversely where a good is scarce consumers are likely to bid up its price in order to ensure that they can consume their desired quantity.

9 This is most likely to arise where products are near substitutes (e.g. oil or most primary products), however even in markets where there are marked differences between products (e.g. the motor or computer industries) consumers can still be quite price sensitive.

10 For example, the costs of oil extraction tend to increase as global stocks decline. 
In order to explore the response to risk of firms competing in an oligopolistic industry, consider a pair of risk neutral quantity-setting duopolists labelled $i=1,2$ with perfectly substitutable outputs $q_{1}$ and $q_{2}$ facing and inverse linear demand curve $p=a-b\left(q_{1}+q_{2}\right)$ where $a, b>0$. Both firms have production functions which display constant returns to a single input $z_{i}$, but are faced with multiplicative technological risk so that $q_{i}=z_{i} \epsilon_{i}$, where $\epsilon_{i} \geq$ 0 are random variables with mean standardised to 1 , variance $\sigma_{i}^{2} \geq 0$, and covariance $\sigma_{12}$. The unit cost of $z_{i}$ is $c$ for both firms. The firms' expected profits are therefore. ${ }^{11}$

$$
E\left[\pi_{i}\left(q_{1}, q_{2}\right)\right]=E\left[a q_{i}-b q_{i}^{2}-b q_{1} q_{2}-c z_{i}\right] \text { for } i=1,2
$$

where $E[$.$] is the expected value operator. To explore the impact of technological risk on the$ firms note that [1] can be written as

$$
E\left[\pi_{i}\left(z_{1}, z_{2}\right)\right]=(a-c) z_{i}-b\left\{\sigma_{i}^{2}+1\right\} z_{i}^{2}-b\left\{\rho \sigma_{1} \sigma_{2}+1\right\} z_{1} z_{2}
$$

where the second and third terms arise from taking the expected value of $\left(-b q_{i}^{2}\right)$ and $\left(-b q_{1} q_{2}\right)$. The covariance between $\epsilon_{1}$ and $\epsilon_{2}$ is $\sigma_{12}=\rho \sigma_{1} \sigma_{2}$ where $\rho$ is the correlation coefficient.

The key point to note is that profit for firm $i$ is a concave function of $q_{i}$ so that, by Jensen's inequality, ${ }^{12} \pi\left(\bar{q}_{i}, q_{j}\right)>E\left[\pi_{i}\right]$ where $\bar{q}_{i}=z_{i}$ is the expected value of output, so that these risk neutral firms prefer certainty to risk. Indeed the expected profits of these oligopolistic firms are reduced by the presence of multiplicative technological risk so long as the demand function $p\left(q_{i}\right)$ is so specified that $d^{2}\left(p q_{i}\right) / d q_{i}^{2}$ is negative - that is, so long as the firms' marginal revenue curves are downward sloping. ${ }^{13}$

Equation [2] demonstrates that technological risk impacts negatively on an oligopolistic firm in three ways: first, firm is' expected profits are decreased by its own output variations via the term $\sigma_{i}^{2}$, second expected profits are decreased by the covariance term to the extent that $\rho$ is positive, and third profits are affected by the technological risk and expected output of its rival. In other words, a firm which competes strategically (in that its output decisions are interdependent with those of its rivals) will be adversely affected by output fluctuations even if it has no risk averse stakeholders, and so can generally be expected to prefer certainty to (technological) risk.

\section{Strategic risk management and insurance decisions}

The previous section demonstrated that a firm which experiences random fluctuations, which lead to variability in its own output (so-called "output risk"), will be able to hinder its rivals' learning processes and expose them to a fluctuating residual demand curve ("demand risk") which can also cause them problems. ${ }^{14}$ In essence a firm's random fluctuations,

\footnotetext{
$"$ A feature of this model is that, whatever the level of output $\left(q_{1}+q_{2}\right)$, the industry price adjusts to "clear" the market.

12 For example, see Eeckhoudt \& Gollier (1992) ch3.

13 Exactly the same result would obtain if technological risk were additive.

${ }^{14}$ Since a perturbation in a firm's output produces fluctuations in the price faced by its rival (see Gal-or 1986, Shapiro 1986, and Young \& Bolbol 1992).
} 
whether they be caused by liability suits, theft, fires or some other potentially insurable event, are not wholly bad: while they may decrease its revenues, they can - by preventing rivals from making the right production decisions - harm its competitors as well. ${ }^{15}$ Thus a firm's insurance and risk management decisions cannot be made in isolation but will depend on the corresponding decisions of its rivals.

Given that oligopolistic firms may dislike risk, any strategy which involves an increase in risk is unlikely to be costless. However, the costs associated with increasing output risk are likely to be less than those of a similar increase in the variability of demand. Movements in price and output tend to be negatively related, consequently, a low level of output is usually associated with a high price and vice versa - for example, Dekel \& Scotchmer (1990) and Doherty \& Smith (1993) note that loss of oil production via spillage can increase oil prices. This negative relationship means that a firm which exposes itself to output risk may find that its income could remain fairly stable because of the compensating movements in price. In essence the firm exposing itself to output risk may benefit from a natural hedge between price and output that protects its income and ultimately the financial investments of its stakeholders. ${ }^{16}$

Table 4: A $2 \times 2$ risk management game

Payoffs to: (Firm 1, Firm 2)

\begin{tabular}{|c|c|c|c|}
\hline \multirow{4}{*}{ Firm 1} & \multicolumn{3}{|c|}{ Firm 2} \\
\hline & & Certainty & Risk \\
\hline & Certainty & $(\mathrm{C}, \mathrm{C})$ & $(\mathrm{A}, \mathrm{B})$ \\
\hline & Risk & $(\mathrm{B}, \mathrm{A})$ & $(\mathrm{R}, \mathrm{R})$ \\
\hline
\end{tabular}

In order to illustrate the implications for a firm's risk management policy (where risk is an endogenous strategic variable) the risk management decision is set up as a static two-bytwo non-cooperative game of complete symmetric information where otherwise identical duopolists choose (simultaneously) between two levels of risk ("Risk" and "Certainty"). Table 4 illustrates the decisions in this risk management game in a quite general way, where

15 One possible way to reduce the costs of this strategy would be for firms to manipulate their rivals perceptions of their output instead of causing actual fluctuations. However, while such a strategy is likely to be quite cheap, it may not be nearly as effective as the real thing (see Ashby \& Diacon, 1996b).

16 The strength of this hedge will depend on the elasticity of demand. Where demand is more elastic, price will not be significantly affected by output thereby reducing the strength of the hedge, the opposite being the case for inelastic demand. However, while the costs associated with increasing output risk may rise when demand is elastic the benefits of such a strategy may also increase. Where demand for a product is elastic consumers tend to be very price sensitive, consequently, even a small change in the price of one firm's product is likely to have a significant affect on the demand for those of its rivals'. Hence with elastic demand a firm need only slightly increase its output fluctuations in order to expose its rivals to significant levels of demand risk. 
the payoffs can represent expected profits or expected utilities. ${ }^{17}$ The size of the payoffs will, of course, depend on the extent to which a firm's choice of "Risk" and "Certainty" benefits itself and/or its rivals, which will in turn depend on the nature of the firms and on the inverse demand curve that they face.

Clearly, the generality of the game illustrated in Table 4 enables a wide variety of possible Nash equilibrium strategies, ${ }^{18}$ depending on the respective size of the payoffs. Even when we restrict attention to symmetric games, there are a number of interesting pure strategy alternatives: ${ }^{19}$

(i) a "Certainty" equilibrium will arise if $C>B$ and $A>R$ so that each firm will earn higher payoffs by choosing certainty whatever the choice of the other. In this case Certainty is a strictly dominating strategy for each firm, and the Nash equilibrium will be (Certainty, Certainty);

(ii) a "Risk" equilibrium will arise if $B>C$ and $R>A$. In this case the Nash equilibrium is (Risk, Risk) and neither firm will control or remove risk. Such a possibility is discussed in a more general manner by Gradstein, Nitzan \& Slutsky (1992);

(iii) two examples of the standard Prisoners' Dilemma. A "Risk War" equilibrium will arise if $B>C>R>A$, when the Nash equilibrium will be (Risk, Risk). On the other hand a "Certainty War"could happen if $A>R>C>B$, in which case each firm spends too much on risk management. These are both case where the strictly dominating strategy equilibrium yields a Pareto inferior solution, and both firms would be better off if they could enforce a cooperative agreement;

(iv) Coordination equilibria will arise if the game yields two symmetric Nash equilibria: for example, when $C>B$ and $R>A$ the equilibria will be (Certainty, Certainty) and (Risk, Risk). In such circumstances, Rasmussen (1994) notes that extra steps (such as mediation and communication) may be necessary in order to achieve the Pareto superior equilibrium: which could well be (Certainty, Certainty) if $C>R$.

This brief discussion reveals two important characteristics of strategic risk management decisions, particularly those involving the purchase of insurance. First when firms compete strategically, the optimum risk strategies of one firm cannot be made in isolation from those of its rivals. In the absence of any strategic interdependence, a firm would choose Certainty over Risk (for example) so long as the payoffs were greater (ie if $C>R$ ), but the preceding discussion shows that the equilibrium (Certainty, Certainty) rarely requires $C>R$, and relies instead on a comparison which takes the other firm's behaviour into account. Indeed case (iii) above shows explicitly that (Certainty, Certainty) may be a strictly dominating equilibrium even though the payoffs in (Risk, Risk) are greater (the fact that $R>C$ implies that firms spend excessively on certainty): this is precisely the case illustrated in the example in the appendix.

${ }_{17}$ A more technical, but specific, example is provided in an appendix, building on Equations [1] and [2] where Certainty is assumed to be when $\sigma_{i}^{2}=0$ and Risk when $\sigma_{i}^{2}=1$.

18 In the usual sense that no one firm/player will want to deviate unilaterally from its predicted strategy given the strategy chosen by its rivals (for example, see Rasmussen, 1994).

${ }^{19}$ Guyer \& Hamburger (1968) note that, in general, there are 726 distinct $2 \times 2$ games. 
Secondly there may be cases (such as (iii) and (iv) above) where the Pareto superior position can only be achieved by utilising additional mechanisms other than a mere comparison of payoffs. In case (iii) a risk war or a certainty war can only be avoided (in a one-stage game) if the rivals can form a binding agreement to choose the Pareto superior alternative which is sufficiently robust to deter them from defecting. In case (iv) where $C>R$, the rivals will not necessarily settle on the Pareto superior equilibrium unless their actions are communicated or coordinated in some way so that they both choose Certainty. ${ }^{20} \mathrm{We}$ will see that, in cases where (Certainty, Certainty) may be preferred, utilising an external agency to control risk (for example, an insurance company) may bring advantages of facilitating coordination or preventing defection, in addition to the more usual risk control function. ${ }^{21}$

\section{Strategic reasons for buying insurance}

By purchasing insurance a firm transfers the financial impact of its fortuitous losses onto the insurer. This may enable the firm, at a price, to protect both itself and its stakeholders against unpredictable fluctuations, thereby stabilising and in some cases increasing both profits and output. However this stabilising function of insurance, which is shared by other risk control devices, may be supplemented by the insurer's ability to facilitate strategic cooperation or coordination between competing firms for their mutual benefit. The joint strategic advantages of insurance may even explain why apparently risk neutral firms purchase insurance.

\section{Insurance as a means of gaining strategic advantage}

The symmetric nature of the payoffs in Table 4 rather disguise the opportunities that firms in oligopolistic industries have for the strategic purchase of insurance (which would be much greater if the two competing firms were not assumed to be identical). However the table shows quite clearly that a firm's insurance decision cannot be made in isolation from that of it's rivals. Thus in the case of the "Certainty War" ((iii) above), if Firm 2 believed that 1 was going to choose Risk, then it would opt for Certainty as this would yield it the highest possible payoff $(A)$. In some circumstances (for example, dynamic games of incomplete information) this might be a feasible strategy. However in a one-shot game of complete information, Firm 1 knows that it cannot choose Risk unilaterally because it's rival will then adopt Certainty thus leaving Firm 1 with the worst possible payoff $(B)$. Similarly if it chooses Certainty, Firm 1 cannot hope that Firm 2 will select Risk. Thus both firms are draw towards the Nash equilibrium of (Certainty, Certainty) and will earn payoff $C$ even though $A>R>C$.

\section{Insurance as a means of avoiding risk wars}

In the previous section we explained how a pair of duopolists might achieve a Nash equilibrium (Risk, Risk) which was Pareto inferior to that which would arise if both firms opted for Certainty. This may arise, for example, if a Prisoners' Dilemma situation emerges in which the strictly dominating equilibrium is (Risk, Risk) even though the payoffs for each Risk.

${ }^{20}$ Defection is not a problem here: if $C>R$ no firm has any incentive to change from Certainty to

21 Of course, insurance brokers and group captives could also be used to enforce a Pareto superior but stricktly dominated non-insurance (Risk, Risk) strategy (for example see Dekel \& Scotchmer, 1990). 
firm would be higher under certainty. The problem with this is that the situation can then degenerate into what we term a "risk war", in which rival firms continually increase their exposure to output risk in an attempt to gain the upper hand and increase their market share. ${ }^{22}$ The net result of a risk war could be rather unpleasant, to both shareholders and other stakeholders. Such wars are likely to be characterised by significant profit fluctuations and even bankruptcies, and - if firms act as if they are risk averse -- a large drop in total industry output. Some reduction in output is not necessarily bad, since it may enable oligopolistic firms to jointly raise the market price and earn increased profits, however in a risk war industry output is likely to fall below desirable levels, thereby intensifying the associated losses. Given the costly effects of risk wars it would appear to be in firms' joint interests to try to control or even prevent them but this is unlikely to be easy. If firms can agree to control their exposure to output fluctuations they should be able to reduce the adverse effects of risk wars and thus increase joint industry profits. However, because of the significant competitive advantage that may be gained by each individual firm from exposing its rivals to demand risk, the incentive to cheat on any such agreement is likely to be very strong. ${ }^{23}$ In short, there is likely to be a conflict between what is best for the group and what is preferred by the individual firm. ${ }^{24}$ Consequently, unless firms can find some kind of enforcement mechanism they are likely to find it very difficult to sustain jointly benefical risk reducing agreements and could well be faced with lengthy risk wars.

It may be that one possible way to help maintain the interests of the group and prevent damaging risk wars is for firms to both purchase insurance and communicate that purchase to rivals. Insurance companies have the ability to both monitor and prevent risk-seeking behaviour within firms (Skogh 1989, 1991; Holderness, 1990). Underwriters tend to be skilled at assessing risk and are likely to react to any increases by demanding higher premiums or refusing subsequent cover. In addition, insurance companies can take advantage of the contract law governing disclosure, since when purchasing insurance the firm is governed by utmost good faith and warranty. Consequently if the firm fails to provide accurate information about material facts or comply with contractual requirements it may well have its claims refused or even face legal proceedings. ${ }^{25}$

There are, however, some problems associated with the use of insurance a strategic device to control risk wars. Firstly insurance premiums are typically experience rated, i.e. rated on the past loss experience of the purchasing firm. The firm which purchases insurance and then increases its exposure to output risk will therefore not be punished by an increase in premiums until some time after such opportunistic behaviour. This (coupled with all the

22 A possible example might be the "tit for tat" formation of captive insurers by competing firms in the same industry.

23 Particularly since so little public information is available about firms' risk-taking and insurance decisions. See Ashby \& Diacon (1996b) for details on how little information stock analysts have about corporate insurance and risk management behaviour.

24 This conflict of interest is a common problem in economic research, for more information see Dixit \& Nalebuff (1991) and McMillan (1992).

25 It is also interesting to note that insurers' tend to punish violations by firms more strictly than would be the case in personal lines business. Punishing individual firms which cheat on risk reducing agreements may actually be of benefit to all. 
usual moral hazard incentives) is likely to increase a firm's incentive to cheat, particularly one with short term investment horizons, since it may be several years before it is forced to bear the full costs of its actions. ${ }^{26}$

Secondly insurance suffers from the classic simultaneous move or "you first" problem. ${ }^{27}$ While all firms may agree that it is in their joint interests to buy insurance, the competitive advantages associated with not purchasing will mean that none may be prepared to make the first move. Consequently unless firms can find some way to ensure that they all buy insurance cover at the same time, they are unlikely to be able to prevent risk wars.

Thirdly the complexity of insurance coverages, and the inherent difficulties in communicating insurance purchases to rivals, may mean that firms can mask the down-grading of their insurance coverage. Even in the event of a major loss, firms may be able to disguise the extent to which the loss is hedged by insurance.

Fortunately, the problems associated with non-simultaneous moves tend to lessen in multi-period and fully dynamic games (Chamberlin 1929, Axelrod 1984, Fudenberg \& Tirole 1986). In repeated games, firms will generally move towards the joint best outcome since they realise that failure to achieve this equilibrium is likely to result in long and costly risk wars. In such cases a firm may even unilaterally purchase insurance, and communicate that fact to its rivals, in the hope that they will follow suit.

The equal and simultaneous take-up of insurance can also be encouraged by making it compulsory under statute or contract for all firms in the same industry. Governments, creditors ${ }^{28}$ and suppliers all typically stipulate minimum insurance requirements for certain risks (perhaps to mitigate the effects of risk wars) and can punish non-compliance through fines, refusal of firm specific inputs, greater interest charges and input prices or even enforced liquidation. However, compulsory insurance requirements do not cover all risks, and even when they are in place the penalties associated with non-compliance can often be small or imperfectly enforced. ${ }^{29}$ The compulsory disclosure of insurance coverage has also been mooted, most notably by Ayling (1985) and the Accounting Standards Board (1993), although not as a solution to the cheating problem.

An alternative enforcement strategy might be for firms in the same industry to use the same insurer, or a joint or group captive, or the same insurance broker (which can monitor the insurance purchases, and warn firms of cancellations). Captives are often a more cost effective way to finance risk than conventional insurance (Aon, 1997), while group captives solve the "you first" problem, since each firm can be required to give advanced notice of its withdrawal from the arrangement.

\section{Insurance as a means of coordination}

The previous section also showed how coordination of strategies could produce Pareto improvements in the case of multiple Nash equilibria. The example given in the appendix could be interpreted as a problem of coordination. In such circumstances, the eventual

${ }^{26}$ This is especially likely for new or low frequency hazards that insurance companies do not have much information on.

${ }^{27}$ Prime examples of this problem include weapons reduction negotiations.

${ }^{28}$ Industry-wide insurance enforcement might arise if all firms used the same merchant bank, and were therefore subject to the same loan covenants, for example.

${ }^{29}$ For example, few regulators, creditors and suppliers are likely to check the true extent of a firm's insurance cover until after a loss has occurred. 
choice of pure strategy depends on the degree of "superiority" of the best equilibrium: if there is an obvious favourite then this will probably emerge as a Schelling focal point (Schelling, 1960). Focal points may also arise as a result of social or cultural convention, ${ }^{30}$ or out of habit, and there is no doubt that, for many years, the corporate purchase of insurance was focal. ${ }^{31}$

In the absence of a clear focal point, firms may be able to improve their position by communicating their strategic choices or employing the services of a mediator who may suggest an equilibrium to all players (Rasmusen, 1994). Since the communication and/or mediation services will improve the payoffs for all players, firms will often be prepared to pay for them. A natural candidate of the role of communicator is the insurance broker or risk management consultant which provides specialist advice to several clients in the same industry.

\section{Conclusions}

The main purpose of this paper has been to discuss the possibility that decisions on corporate insurance purchases may have a strategic dimension. The conventional literature has focused on the ability of insurance to add value to the firm by limiting the impact of risk on risk averse stakeholders or reducing the cost of such risk. The key argument in this paper is that, under certain circumstances, the corporate demand for insurance may be motivated by a company's strategic decisions on output and price risk.

Despite the unusual theoretical basis of our research it is worth noting that in many ways the role of insurance and other risk transfer/financing devices has not really changed in any great way. Modern corporate insurance theory (Skogh, 1989, 1991; Grillet 1992) has largely focused on the monitoring role of insurance and its ability to prevent opportunistic behaviour between stakeholders. In this respect our research is no different. In the strategic context insurance/alternative risk financing devices also have a monitoring role to play, however, rather than focus on all the conventional issues we have introduced a new stakeholder group worthy of consideration - the firm's competitors.

Most real world markets are characterised by small numbers of relatively large firms which compete with each other strategically. By focusing on such oligopolistic markets we reveal that this interdependency between firms means that insurance and risk management can also have a strategic consequence. The strategic behaviour of the firm may influence risk management in general, and the corporate purchase of insurance in particular, in three main ways. First, the strategic nature of competition may provide an incentive for even risk neutral firms to control technological risk arising from output fluctuations. This occurs because a firm which has some control over its price is likely to have a profit function which is concave in output.

30) Many experimenters have noted, for example, that risk avoidance decisions which are framed as insurance produce a more risk averse response - for example, see Lypny (1993).

31 "The insurance function started with the insurance clerk who kept records of policies in force. That position evolved into the insurance buyer and then the insurance manager. The current vogue is "risk manager". Yet while the concept of risk management is considerably broader than insurance alone, the risk manager is still inextricably anchored to the insurance system. The title has changed but not the function... Thus, until the risk manager can be completely free of his real and psychological ties to insurance and the insurance industry, he will not be able to perform the risk management function." Kloman (1971). 
Secondly the firm's risk control decisions cannot be made in isolation but will depend on the actions of its rivals. It is possible, for example, that firms will choose to adopt high risk strategies even though low risk ones would yield a Pareto improvement in terms of higher payoffs for all competitors. The opposite is also possible however: the example in the appendix shows that firms which dislike risk spend too much on insurance.

Thirdly insurance (as opposed to other risk control mechanisms) may play a role in facilitating cooperation or coordination between competiting firms for their mutual benefit in order to achieve a Pareto superior low-risk outcome. Similarly firms which wish to avoid over-investing in certainty may be able utilise other coordinating mechanisms (such as brokers or group captives - but presumably not insurance) to reduce their insurance coverage.

Finally the analysis and descriptions in this paper have been undertaken within the fairly narrow confines of a simultaneous move game of full symmetric information in order to try to establish corporate insurance purchases in a strategic setting. It would be realistic, and indeed more interesting, for future research to recognise that firms often know very little about the insurance purchases of their rivals ${ }^{32}$ (ie information is incomplete) and make their decisions in a dynamic context.

\section{Acknowledgements}

* Simon Ashby wishes to thank the Association of British Insurers for financial support.

* The authors wish to acknowledge the useful comments by two referees.

32 Very little information is normally revealed publicly about a firm's insurance coverage. 


\section{APPENDIX}

\section{An Example of a Cournot-Nash Risk Management Game}

Consider a pair of risk neutral duopolists labelled $i=1,2$ with perfectly substitutable outputs $q_{1}$ and $q_{2}$ facing a linear inverse demand curve $p=a-b\left(q_{1}+q_{2}\right)$, where $a, b>0$. Both firms have production functions which display constant returns to a single input $\mathrm{z}_{\mathrm{i}}$, but are faced with multiplicative technological risk so that $\mathrm{q}_{\mathrm{i}}=\mathrm{z}_{\mathrm{i}} \varepsilon_{\mathrm{i}}$, where $\varepsilon_{\mathrm{i}}$, $\geqslant 0$ are random variables with mean standardised to 1 , variance $\sigma_{i}^{2} \geqslant 0$, and covariance $\sigma_{12}$. The unit cost of $z_{i}$ is $c$ for both firms. The firms' expected profits are therefore

$$
\mathrm{E}\left[\pi_{\mathrm{i}}\left(\mathrm{z}_{1}, \mathrm{z}_{2}\right)\right]=(\mathrm{a}-\mathrm{c}) \mathrm{z}_{\mathrm{i}}-\mathrm{b}\left\{\sigma_{\mathrm{i}}^{2}+1\right\} \mathrm{z}_{1}^{2}-\mathrm{b}\left\{\rho \sigma_{1} \sigma_{2}+1\right\} \mathrm{z}_{1} \mathrm{z}_{2}
$$

The covariance between $\varepsilon_{1}$ and $\varepsilon_{2}$ is $\sigma_{12}=\rho \sigma_{1} \sigma_{2}$ where $\rho$ is the correlation coefficient. the firms then choose inputs $z_{i}$ to maximise expected profits $E\left[\pi_{i}\right]$ and the first-order condition for a Cournot-Nash equilibrium is

$$
\partial E / \partial z_{i}=(a-c)-2 b\left\{\sigma_{i}^{2}+1\right\} z_{1}-b\left\{\rho \sigma_{1} \sigma_{2}+1\right\} z_{j}=0 \quad \text { for } i, j=1,2 ; i \neq j .
$$

Some tedious computation then yields the optimal values $\mathrm{z}^{*}{ }_{\mathrm{i}}$ where

$$
z_{i}{ }_{i}=\frac{\frac{(a-c)}{b} \cdot\left[2\left(\sigma_{f}^{2}+1\right)-\left(\rho \sigma_{1} \sigma_{2}+1\right)\right]}{4\left(\sigma_{1}^{2}+1\right)\left(\sigma_{2}^{2}+1\right)-\left(\rho \sigma_{1} \sigma_{2}+1\right)^{2}} \text { for } i \neq j
$$

The second-order conditions for a maximum require $\partial^{2} \mathrm{E} / \partial \mathrm{z}_{\mathrm{i}}^{2}$ to be negative and the Hessian determinant $|\mathrm{H}|=\left(\partial^{2} \mathrm{E} / \partial \mathrm{z}_{2}^{2}\right) \cdot\left(\partial^{2} \mathrm{E} / \partial \mathrm{z}_{2}{ }^{2}\right)-\left(\partial^{2} \mathrm{E} / \partial \mathrm{z}_{1} \partial \mathrm{z}_{2}\right)^{2}>0$. We have $\partial^{2} \mathrm{E} / \partial \mathrm{z}_{\mathrm{i}}{ }^{2}=-$ $2 \mathrm{~b}\left(\sigma_{\mathrm{i}}{ }^{2}+1\right)<0$ and $\partial^{2} \mathrm{E} / \partial \mathrm{z}_{1} \partial \mathrm{z}_{2}=-\mathrm{b}\left\{\rho \sigma_{1} \sigma_{2}+1\right\}$ so that the final second-order condition is satisfied in circumstances when the denominator of the expression for $\mathrm{Z}^{*}{ }_{\mathrm{i}}$ is positive.

The table below shows the symmetric $2 \times 2$ Risk Management Game of Table 4, where the payoffs are the expected profits obtained by substituting the optimal values for $\mathrm{z}^{*}{ }_{i}$ into $E\left[\pi_{i}\left(z_{1}, z_{2}\right)\right]$. The lump-sum insurance premium $P_{C C}$ an $P_{C R}$ are those payable in the (Certainty, Certainty), and (Certainty, Risk) and (Risk, Certainty) cases respectively. All payoffs are expressed in units of $(a-c)^{2} / b$.

\section{Firm 2}

Firm 1

$$
\text { Certainty, } \sigma_{2}=0 \quad \text { Risk, } \sigma_{2}=1
$$

$$
\begin{array}{lll}
\text { Certainty, } \sigma_{1}=0 & \left(1 / 9-\mathrm{P}_{\mathrm{CC}}, 1 / 9-\mathrm{P}_{\mathrm{CC}}\right) & \left(9 / 49-\mathrm{P}_{\mathrm{CR}}, 2 / 49\right) \\
\text { Risk, } \sigma_{1}=1 & \left(2 / 49,9 / 49-\mathrm{P}_{\mathrm{CR}}\right) & \left(2 /(\rho+5)^{2}, 2 /(\rho+5)^{2}\right)
\end{array}
$$

In this game, the role of insurance is to remove the impact of technological risk so that output $\mathrm{q}_{\mathrm{i}}=\mathrm{z}_{\mathrm{i}}$. The lump-sum premiums $\mathrm{P}_{\mathrm{CC}}$ and $\mathrm{P}_{\mathrm{CR}}$ enable the insurer to appropriate some of the benefits that firms gain as a result increased output and higher profits under certainty. The Cournot-Nash equilibrium in this game depends on the sizes of $P_{C C}$ and $P_{C R}$. Note that, in this example, a risk war is not a possibility because 2/49 is never greater than $2 /(\rho+5)^{2}$. There are therefore four main cases:

(1) a "Certainty" equilibrium, where both firm insure, will arise if $1 / 9-\mathbf{P}_{\mathrm{CC}}>2 / 49$ and $9 / 49-P_{C R}>2 /(\rho+5)^{2}$ 
(2) a "Risk" equilibrium occurs when $1 / 9-P_{C C}<2 / 49$ and $9 / 49-P_{C R}<2 /(\rho+5)^{2}$

(3) a "Certainty war" where $9 / 49-P_{C R}>2 /(\rho+5)^{2}>1 / 9-P_{C C}>2 / 49$

(4) a pair of "Coordination" equilibria (Certainty, Certainty) and (Risk, Risk) occur if $1 / 9-\mathrm{P}_{\mathrm{CC}}>2 / 49$ and $9 / 49-\mathrm{P}_{\mathrm{CR}}<2 /(\rho+5)^{2}$. The (Certainty, Certainty) equilibrium will be Pareto superior if $1 / 9-\mathrm{P}_{\mathrm{CC}}>2 /(\rho+5)^{2}$

Finally, we note that if the 'insurer' wishes to generate the same premium revenue $P$ irrespective of whether one or both firms insure then we must have $\mathrm{P}=\mathrm{P}_{\mathrm{CC}}=0.5 \mathrm{P}_{\mathrm{CR}}$. So when $\rho=0$, insurance is only purchased if $P<0.05183$ since case (2) requires $P>0.0703$ while in case (4) $0.05183<\mathrm{P}<0.0703$ and (Risk, Risk) is the Pareto superior equilibrium. Thus $\mathbf{P}<0.05183$ is sufficient to produce a (Certainty, Certainty) Nash equilibrium, but this will generate a "Certainty war" if $0.05183>\mathrm{P}>0.03111$ since each firm then receives a payoff which is Pareto inferior to the 0.08 of (Risk, Risk).

\section{BIBLIOGRAPHY}

ACCOUNTING STANDARDS BOARD (1993), Operating and Financial Review, July, London.

AON (1997), 1997 Biennial Risk Financing and Insurance Survey, Aon Risk Services, London.

ARROW, K. (1963), Social Choice and Individual Value, John Wiley \& Sons Inc: New York.

ASHBY, S. and DIACON, S. (1996a) "The Value of Corporate Risk Management: Empirical Evidence from Large UK Companies", Risk, Decision and Policy, Vol. 1, No 2, pp. 203-216.

ASHBY, S. and DIACON, S. (1996b), "The Strategic Value of Silence: The Costs and Benefits of Communication in Risk and Crisis Management", Proceedings of the Third Annual European Conference on Risk and Crisis Management, University of Bradford, February. 
AXELROD, R. (1984), The Evolution of Co-operation, New York: Basic Books.

AYLING, D. (1985), "Should Corporate Buyers Disclose Their Insurance Coverage?", Proceedings of the 7th UK Insurance Economists Conference, University of Nottingham, April.

CADBURY, Sir A. (1992), Committee on the Financial Aspects of Corporate Governance, Gee \& Co. Ltd., London.

CHAMBERLIN, E. (1929), "Duopoly: Value Where Sellers are Few", Quarterly Journal of Economics, Vol. 40, pp. 63-100.

CENTRAL STATISTICS OFFICE (1992), Business Monitor - Report on the Census of Production, HMSO.

DEKEL, E. and SCOTCHMER, S. (1990), "Collusion Through Insurance: Sharing the Cost of Oil Spill Cleanups", American Economic Review, Vol. 80, pp. 249-252.

DIACON, S. (1991), "The Effect of Increased Product-Market Competition on the Purchase of Insurance", Insurance Law and Practice, Vol. 1, No 2, pp. 61-64.

DIXIT, E. and NALEBUFF, B. (1991), Thinking Strategically, Oxford University Press.

DOHERTY, N. and SMITH, C. (1993), "Corporate Insurance Strategy: The Case of British Petroleum", Journal of Applied Corporate Finance, Vol. 6, pp. 4-15.

EECKHOUDT, L. and GOLLIER, C., Risk: Evaluation, Management and Sharing, Harvester Wheatsheaf, Hemel Hempstead, UK.

FREEMAN, P. and KUNREUTHER, H. (1996), "The Roles of Insurance and Well-Specified Standards in Dealing with Environmental Risks", Managerial and Decision Economics, Vol. 17, pp. 517-530.

FUDENBERG, D. and TIROLE, J. (1986), Dynamic Models of Oligopoly, Harwood Academic Publishers.

GAL-OR, E. (1986), "Information Transmission: Cournot and Bertrand Equilibria", Review of Economic Studies, Vol. 53, pp. 85-92.

GARVEN, J. and LOUBERGÉ, H. (1996), "Reinsurance, Taxes, and Efficiency: A Contingent Claims Model of Insurance Market Equilibrium", Journal of Financial Intermediation, Vol. 5, No 1, pp. 74-93.

GRADSTEIN, M., NITZAN, S. and SLUTSKY, S. (1992), "The Effect of Uncertainty on Interactive Behaviour", The Economic Journal, Vol. 102, pp.554-561.

GRAVELLE, H. and REES, R. (1992), Microeconomics, 2nd ed, Longman, London.

GRILLET, L. (1992), "Corporate Insurance and Corporate Stakeholders: ITransaction Costs Theory", Journal of Insurance Regulation, Vol. 11, No 3, pp. 233-251.

TOWERS PERRIN (1994), Cost of Risk Survey, Towers Perrin Risk Management Publications, Stamford, CT.

TUFANO, P. (1996), "Who Manages Risk? An Empirical Examination of Risk Management Practices in the Gold Mining Industry", The Journal of Finance, Vol. 51, No 4, pp. 1097-1137.

WILLIAMS, C., SMITH, M. and YOUNG, P. (1995), Risk Management and Insurance, 7th ed, McGraw-Hill, New York.

YOUNG, L. and BOLBOL, A. (1992), "Output Fluctuations as Entry Deterrence a Model of Predatory Pricing", Canadian Journal of Economics, Vol. 25, pp. 89-110. 